\section{'Hall': An Early-season Self-fertile Bronze Muscadine Grape}

Patrick J. Conner ${ }^{1}$

University of Georgia-Tifton Campus, 2360 Rainwater Road, Tifton, GA 31793

Additional index words. breeding, Muscadinia rotundifolia, Vitis rotundifolia

'Hall' is a self-fertile bronze-colored muscadine grape (Vitis rotundifolia Michx.) that is being released by the University of Georgia (UGA) College of Agriculture and Environmental Sciences. 'Hall' produces good yields of medium- to large-sized berries with excellent taste suitable for the fresh market. 'Hall' berries have exceptionally low levels of pedicel scar splits and tears, leading to a high percentage of usable berries. 'Hall' has an early harvest date with an average first pick of 31 July in Tifton, GA. Berry color of 'Hall' is noticeably brighter and more yellow than most bronze cultivars. 'Hall' is recommended as a self-fertile bronze muscadine for early fresh-market sales.

\section{Origin}

'Hall' originated in Tifton, GA, from a cross of 'Fry' by 'Tara' (Fig. 1) made in 2001 by Melvin Hall at the UGA-Tifton Campus. Selection of 'Hall' and all subsequent testing was performed by Patrick Conner. 'Fry' is a midseason female bronze cultivar with excellent flavor (Conner, 2009). within the row and $4.5 \mathrm{~m}$ between rows. Vines at Wray were spaced $6.1 \mathrm{~m}$ between plants within the row and $3.7 \mathrm{~m}$ between rows. All vines were trained to a single wire trellis with two cordons per vine. Drip irrigation was used and diseases and insects were controlled according to commercial guidelines (Poling et al., 2003).

Vine vigor was calculated by measuring the caliper of the trunk $75 \mathrm{~cm}$ above the ground before budbreak. Vine yields were estimated in Years 3 and 4 by harvesting fruit from $1 \mathrm{~m}$ of the interior cordon (cordon most distal to the trellis post) and then multiplying the sample yield by the total cordon length. Vines were harvested from one to four times depending on the uniformity of ripening with the first harvest occurring as soon as approximately half of the berries were ripe. Once the yield was weighed to give the total yield weight, the berries were then sorted. Berries with any visible signs of decay were removed 'Tara' has perfect flowers, making it selffertile, and produces bronze berries with dry pedicel scars that ripen early in the muscadine harvest season (Conner, 2009; Lane, 1993). The original 'Hall' vine first fruited in 2004. Because of its light berry color, early harvest date, productivity, and dry stem scar, it was propagated for further trials as Ga. 1-1-48.

\section{Methods}

Testing locations were Tifton, GA (lat.

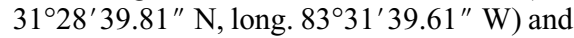
Wray, GA (lat. $31^{\circ} 32^{\prime} 46.59^{\prime \prime} \mathrm{N}$, long. $\left.83^{\circ} 4^{\prime} 49.04^{\prime \prime} \mathrm{W}\right)$. The Tifton trial took place on UGA experimental farms, and the Wray trial was located in a commercial vineyard. 'Fry', 'Lane', 'Tara', and 'Triumph' vines were included as control cultivars at Tifton, and 'Tara' was included as a control cultivar at Wray. Four vines of each cultivar were planted in 2010 at both locations. Vines at Tifton were spaced $3.0 \mathrm{~m}$ between plants

Received for publication 18 Feb. 2014. Accepted for publication 20 Feb. 2014.

${ }^{1}$ To whom reprint requests should be addressed; e-mail pconner@uga.edu.

t.

Fig. 1. Pedigree of 'Hall' muscadine.

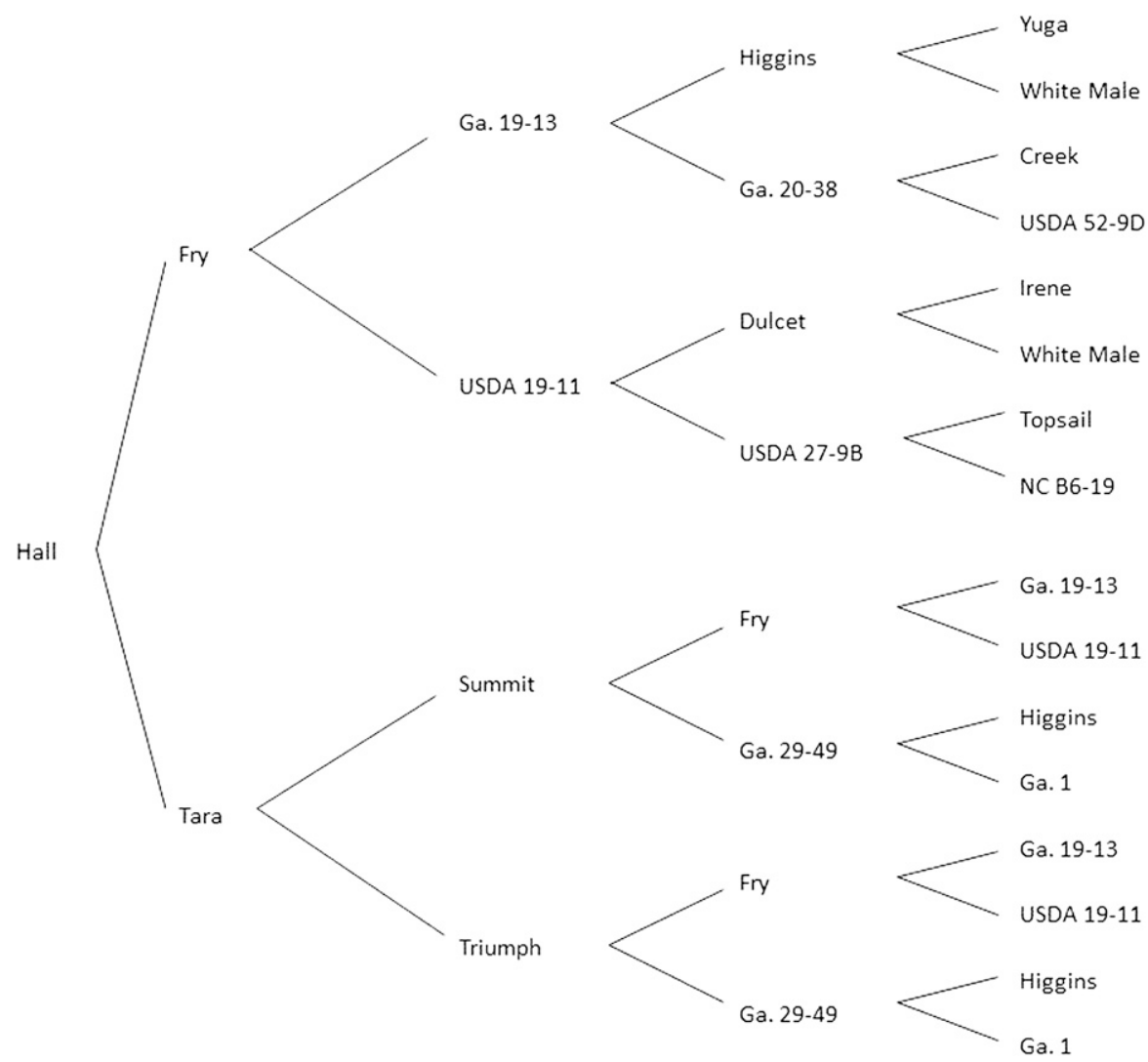

and weighed to calculate percent berry rot. Of the undecayed berries, berries were sorted into those that had pedicel scar splits (large cracks in which the interior flesh was visible), pedicel scar tears (peeling back of the berry epidermis), and dry pedicel scars. Percentage of each of these categories was calculated by dividing the weight of each category by the total weight of all three categories and then multiplying by 100 . Rotted berries and berries with pedicel scar split are commonly removed before packing fruit, so percent usable yield was calculated by the equation $100 \times(1-$ $\%$ berry $\operatorname{rot} / 100) \times(1-\%$ pedicel scar split/ 100). Ten berries were then randomly selected from the usable yield sample and measured for berry weight and diameter. All 10 berries were then crushed together to provide juice to determine percent soluble solids.

Berry skin color was measured on first harvest berries at the equator of the berry using a Konica Minolta CR-400 (8-mm aperture, D65 illuminant) handheld colorimeter (Konica Minolta, Ramsey, NJ). The colorimeter was calibrated with a white standard calibration plate, and color was measured as $\mathrm{L}^{*}, \mathrm{a}^{*}, \mathrm{~b}^{*}$ coordinates. A single measurement was recorded for each berry and 25 replicate berries were measured for each cultivar. The value of $L^{*}$ describes the degree of darkness or lightness with $\mathrm{L}=$ 0 being black and $\mathrm{L}=100$ white. Before analysis, $\mathrm{a}^{*}$ and $\mathrm{b}^{*}$ coordinates were transformed into chroma $\left(C^{*}\right)$ and hue angle $\left(h^{\circ}\right)$ using the equations: $\mathrm{C}^{*}=\left(\mathrm{a}^{* 2}+\mathrm{B}^{* 2}\right)^{1 / 2}$ and 


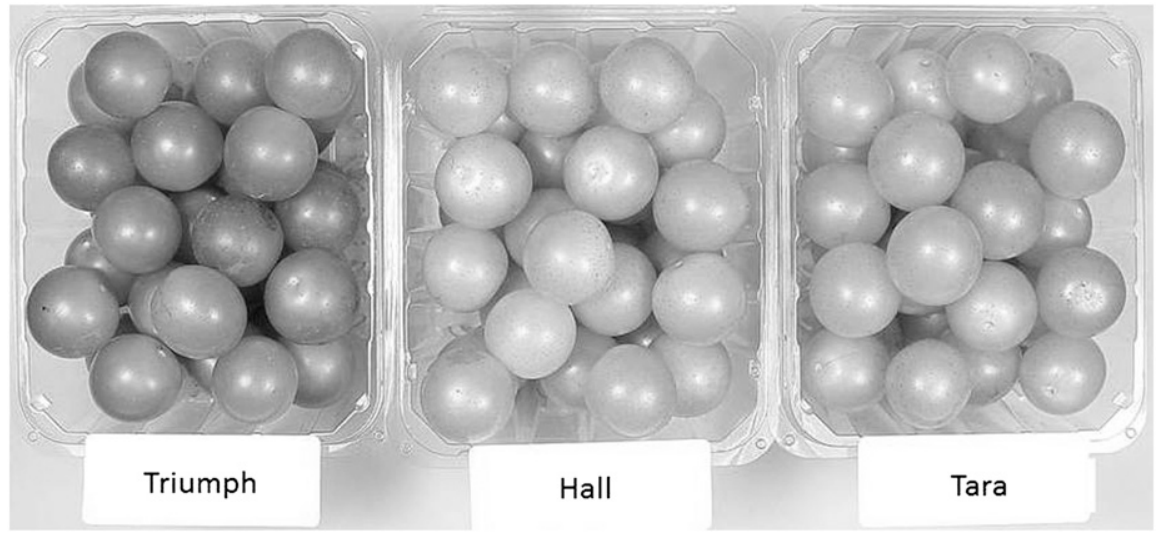

Fig. 2. Ripe berries of 'Triumph', 'Hall', and 'Tara' in pint clamshells.

Table 1. Vine caliper of 'Hall' and standard muscadine cultivars after the first 3 years of growth at Tifton and Wray, GA.

\begin{tabular}{lccc}
\hline Cultivar & 2011 caliper $(\mathrm{mm})$ & 2012 caliper $(\mathrm{mm})$ & 2013 caliper $(\mathrm{mm})$ \\
\hline Tifton, GA & & & \\
Hall & $7.2 \mathrm{c}^{\mathrm{z}}$ & 23.9 & 33.4 \\
Fry & $11.6 \mathrm{a}$ & 26.5 & 35.1 \\
Lane & $8.4 \mathrm{bc}$ & 22.8 & 30.5 \\
Tara & $10.6 \mathrm{ab}$ & 26.4 & 33.3 \\
Triumph & $9.7 \mathrm{abc}$ & 24.8 & 35.5 \\
Significance & 0.031 & $\mathrm{NS}$ & $\mathrm{NS}$ \\
& & & \\
Wray, GA & & 20.4 & 27.5 \\
Hall & 7.0 & 20.3 & 27.6 \\
Tara & 6.7 & $\mathrm{NS}$ & $\mathrm{NS}$ \\
Significance & $\mathrm{NS}$ & & \\
\hline
\end{tabular}

${ }^{2}$ Caliper measured on the trunk $75 \mathrm{~cm}$ aboveground before budbreak. Mean separation within columns by Duncan's multiple range test, $P<0.05$, with $\mathrm{n}=4$.

NS $=$ nonsignificant.

Table 2. Yield ( $\mathrm{kg} / 3-\mathrm{m}$ vine) and berry quality attributes of 'Hall' and standard muscadine cultivars at Tifton, GA, in the third and fourth years of growth (2012-13).

\begin{tabular}{|c|c|c|c|c|c|c|c|}
\hline Cultivar & $\begin{array}{l}\text { Total } \\
\text { yield } \\
(\mathrm{kg})\end{array}$ & $\begin{array}{c}\text { Percent } \\
\text { berry } \text { rot }^{\mathrm{z}}\end{array}$ & $\begin{array}{c}\text { Percent } \\
\text { pedicel scar } \\
\text { split }^{y}\end{array}$ & $\begin{array}{c}\text { Percent } \\
\text { pedicel scar } \\
\text { tear }^{x}\end{array}$ & $\begin{array}{c}\text { Percent } \\
\text { dry pedicel } \\
\text { scar }^{\mathrm{w}}\end{array}$ & $\begin{array}{l}\text { Percent } \\
\text { usable } \\
\text { yield }^{v}\end{array}$ & $\begin{array}{l}\text { Usable } \\
\text { yield } \\
(\mathrm{kg})^{\mathrm{v}}\end{array}$ \\
\hline \multicolumn{8}{|l|}{ Year 3} \\
\hline Hall & $14.6 \mathrm{~b}^{\mathrm{u}}$ & $23.2 \mathrm{a}$ & $4.0 \mathrm{c}$ & $9.0 \mathrm{~b}$ & $87.0 \mathrm{a}$ & $73.7 \mathrm{ab}$ & $11.0 \mathrm{~b}$ \\
\hline Fry & $11.7 \mathrm{~b}$ & $15.3 \mathrm{ab}$ & $34.1 \mathrm{a}$ & $30.7 \mathrm{a}$ & $35.2 \mathrm{c}$ & $55.9 \mathrm{c}$ & $7.4 \mathrm{~b}$ \\
\hline Lane & $12.9 \mathrm{~b}$ & $2.8 \mathrm{c}$ & $30.8 \mathrm{a}$ & $29.3 \mathrm{a}$ & $40.0 \mathrm{c}$ & $67.2 \mathrm{bc}$ & $8.6 \mathrm{~b}$ \\
\hline Tara & $19.1 \mathrm{ab}$ & $19.2 \mathrm{a}$ & $6.4 \mathrm{bc}$ & $15.4 \mathrm{~b}$ & $78.2 \mathrm{a}$ & $75.6 \mathrm{ab}$ & $15.1 \mathrm{~b}$ \\
\hline Triumph & $25.9 \mathrm{a}$ & $4.3 \mathrm{bc}$ & $9.3 \mathrm{~b}$ & $34.3 \mathrm{a}$ & $56.4 \mathrm{~b}$ & $86.8 \mathrm{a}$ & $23.1 \mathrm{a}$ \\
\hline Significance & 0.021 & 0.011 & $<0.001$ & 0.003 & $<0.001$ & 0.008 & $<0.001$ \\
\hline \multicolumn{8}{|l|}{ Year 4} \\
\hline Hall & $20.8 \mathrm{ab}$ & $2.6 \mathrm{c}$ & $2.5 \mathrm{~d}$ & $5.7 \mathrm{~d}$ & $91.8 \mathrm{a}$ & $95.0 \mathrm{a}$ & $19.8 \mathrm{a}$ \\
\hline Fry & $8.7 \mathrm{~d}$ & $10.1 \mathrm{~b}$ & $13.9 \mathrm{~b}$ & $32.8 \mathrm{a}$ & $53.4 \mathrm{c}$ & $77.7 \mathrm{~b}$ & $6.8 \mathrm{c}$ \\
\hline Lane & $13.5 \mathrm{c}$ & $6.0 \mathrm{bc}$ & $24.1 \mathrm{a}$ & $19.4 \mathrm{c}$ & $56.5 \mathrm{c}$ & $71.3 \mathrm{~b}$ & $9.6 \mathrm{c}$ \\
\hline Tara & $15.8 \mathrm{bc}$ & $1.6 \mathrm{c}$ & $5.9 \mathrm{~cd}$ & $7.5 \mathrm{~d}$ & $86.5 \mathrm{a}$ & $92.6 \mathrm{a}$ & $14.7 \mathrm{~b}$ \\
\hline Triumph & $24.0 \mathrm{a}$ & $17.9 \mathrm{a}$ & $7.1 \mathrm{c}$ & $26.8 \mathrm{~b}$ & $66.1 \mathrm{~b}$ & $76.3 \mathrm{~b}$ & $18.3 \mathrm{ab}$ \\
\hline Significance & $<0.001$ & $<0.001$ & $<0.001$ & $<0.001$ & $<0.001$ & $<0.001$ & $<0.001$ \\
\hline
\end{tabular}

${ }^{2}$ Percentage of berries with visible signs of decay or fungal pathogens.

'Percentage of berries that split open at the pedicel scar.

${ }^{x}$ Percentage of berries in which the skin tears at the pedicel scar.

wercentage of berries with no splitting or tearing at the pedicel scar after picking.

vUsable yield is total yield minus weight of rotted berries and berries with pedicel scar splitting.

"Mean separation within columns by Duncan's multiple range test, $P<0.05$, with $\mathrm{n}=4$.

$h^{\circ}=\tan ^{-1}\left(\mathrm{~b}^{*} / \mathrm{a}^{*}\right)$ (McGuire, 1992). Richness of color is represented by $\mathrm{C}^{*}$ and $h^{\circ}$ represents the dominant color wavelength where $0^{\circ}=$ red-purple, $90^{\circ}=$ yellow, $180^{\circ}=$ bluish green, $270^{\circ}=$ blue.
Differences between cultivars were determined using one-way analysis of variance with mean separation by Duncan's multiple range test $(P<0.05)$. Percentage data were analyzed after arcsine-square root transformation.
Statistical analysis was performed using SigmaPlot 12.3 statistical software (Systat Software, San Jose, CA).

\section{Description and Performance}

Vines of 'Hall' are self-fertile and have moderate vigor as measured by vine caliper (Table 1). Leaves average $10.5 \mathrm{~cm}$ in length and $8.5 \mathrm{~cm}$ in width. Lateral canes are drooping and usually grow $1.5 \mathrm{~m}$ or more in a season at Tifton, GA. Typical cane diameter is 3 to $10 \mathrm{~mm}$ and internode length ranges from 3 to $5 \mathrm{~cm}$ (data not shown). Total yields from 'Hall' at Tifton were lower than 'Triumph' and equal to the other control cultivars in Year 3 and equal to 'Triumph' and higher than 'Fry' and 'Lane' in Year 4 (Table 2). In the Wray, GA, trial, 'Hall' had similar yields to 'Tara' in Years 3 and 4 (Table 3). 'Hall' had excellent low levels of pedicel scar split and pedicel scar tear at both locations each year. Berry rot was high in Year 3 at Tifton and Year 4 in Wray but was equal or superior to 'Fry' and 'Tara' (Tables 2 and 3). Percent usable yield and total usable yield was as good or better than all control cultivars except 'Triumph' in Year 3 at Tifton (Tables 2 and 3 ).

Average first harvest of 'Hall' was 31 July (Table 4), which was similar to the early control cultivars (Lane, Tara, and Triumph), and $17 \mathrm{~d}$ before the first harvest of the main season control cultivar Fry. Average percent of the total yield of the first harvest was $59.3 \%$, and percent soluble solids of the first harvest was $14.6 \%$, which was similar to the other early cultivars tested. At maturity, the berries of 'Hall' are round and average $10.6 \mathrm{~g}$ in weight and $26.2 \mathrm{~mm}$ in diameter (Table 5). Berry size is similar to the other self-fertile cultivars but smaller than the female cultivar Fry. Skin of 'Hall' is more friable than 'Fry' and 'Triumph' but not as much as 'Lane' as measured by berry penetration work (Conner, 2013). Flesh firmness is more firm than 'Fry' but less than 'Lane' (Conner, 2013). The color of 'Hall' berries is a bright yellowish green (Fig. 2). 'Hall' is lighter color than 'Fry', 'Tara', and 'Triumph' and more yellow in color than 'Tara' (Table 6).

Symptoms of Pierce's disease have not been observed on 'Hall' at any location. Under a typical fungicide schedule, 'Hall' was susceptible to various fruit rots including bitter rot [Greeneria uvicola (Berk. \& Curt.) Punithalingam, syn. Melanconium fuligineum (Scribner \&Viala) Cav.], ripe rot [Colletotrichum gloeosporioides (Penz.) Penz. \& Sacc.], and macrophoma rot [Botryosphaeria dothidea (Moug. Ex Fr.) Ces. \& de Not]. Infection levels varied by year (Tables 2 and 3 ) and were similar to the other bronze cultivars tested. Growers should expect to apply fungicides to control fruit rotting fungi and pick fruit promptly. Angular leaf spot (Mycosphaerella angulata Jenkins) was observed during the late season at levels similar to the other cultivars tested. 
Table 3. Yield (kg/6.1-m vine) and berry quality attributes of 'Hall' and 'Tara' in Wray, GA, in the third and fourth years of growth (2012-13).

\begin{tabular}{|c|c|c|c|c|c|c|c|}
\hline Cultivar & $\begin{array}{l}\text { Total } \\
\text { yield } \\
(\mathrm{kg})\end{array}$ & $\begin{array}{l}\text { Percent } \\
\text { berry } \operatorname{rot}^{\mathrm{z}}\end{array}$ & $\begin{array}{c}\text { Percent } \\
\text { pedicel scar } \\
\text { split }^{\mathrm{y}}\end{array}$ & $\begin{array}{c}\text { Percent } \\
\text { pedicel scar } \\
\text { tear }^{\mathrm{x}}\end{array}$ & $\begin{array}{c}\text { Percent } \\
\text { dry pedicel } \\
\text { scar }^{w}\end{array}$ & $\begin{array}{l}\text { Percent } \\
\text { usable } \\
\text { yield }^{\mathrm{v}}\end{array}$ & $\begin{array}{l}\text { Usable } \\
\text { yield } \\
(\mathrm{kg})^{\mathrm{v}}\end{array}$ \\
\hline \multicolumn{8}{|l|}{ Year 3} \\
\hline Hall & 26.9 & 15.7 & $3.5 b^{\mathrm{u}}$ & 12.9 & 83.6 & 81.3 & $22.3 \mathrm{a}$ \\
\hline Tara & 16.3 & 25.1 & $9.6 \mathrm{a}$ & 19.7 & 70.8 & 67.8 & $11.4 \mathrm{~b}$ \\
\hline Significance & NS & NS & 0.018 & NS & NS & NS & 0.019 \\
\hline \multicolumn{8}{|l|}{ Year 4} \\
\hline Hall & 20.6 & 25.9 & 5.6 & 11.9 & 82.5 & 69.9 & 14.0 \\
\hline Tara & 13.3 & 34.9 & 10.4 & 8.8 & 80.8 & 58.4 & 8.0 \\
\hline Significance & NS & NS & NS & NS & NS & NS & NS \\
\hline
\end{tabular}

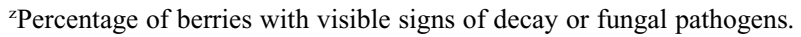

${ }^{y}$ Percentage of berries that split open at the pedicel scar.

${ }^{x}$ Percentage of berries in which the skin tears at the pedicel scar.

wercentage of berries with no splitting or tearing at the pedicel scar after picking.

'Usable yield is total yield minus weight of rotted berries and berries with pedicel scar splitting.

"Mean separation within columns by Duncan's multiple range test, $P<0.05$, with $\mathrm{n}=4$.

NS $=$ nonsignificant

Table 4. Average first harvest day, percent yield and soluble solids of first harvest of 'Hall' and standard muscadine cultivars at Tifton, GA, in years 2012-13.

\begin{tabular}{lccc}
\hline Cultivar & $\begin{array}{c}\text { Avg d of first harvest } \\
\text { (day of year) }\end{array}$ & $\begin{array}{c}\text { Percent of total yield } \\
\text { of first harvest }\end{array}$ & $\begin{array}{c}\text { Percent soluble solids } \\
\text { of first harvest }\end{array}$ \\
\hline Hall & $212 \mathrm{~b}^{\mathrm{z}}$ & 59.3 & 14.6 \\
Fry & $229 \mathrm{a}$ & 60.8 & 14.2 \\
Lane & $215 \mathrm{~b}$ & 58.3 & 14.6 \\
Tara & $213 \mathrm{~b}$ & 46.4 & 13.4 \\
Triumph & $216 \mathrm{~b}$ & 40.5 & 14.7 \\
Significance & $<0.001$ & $\mathrm{NS}$ & $\mathrm{NS}$ \\
\hline
\end{tabular}

${ }^{\mathrm{z}}$ Mean separation within columns by Duncan's multiple range test, $P<0.05$, with $\mathrm{n}=4$.

NS $=$ nonsignificant.

Table 5. Flower and fruit attributes of 'Hall' and standard muscadine cultivars at Tifton, GA, in years 2011-13.

\begin{tabular}{lclccc}
\hline Cultivar & $\begin{array}{c}\text { Flower } \\
\text { type }^{\mathrm{z}}\end{array}$ & Berry color & $\begin{array}{c}\text { Berry wt } \\
(\mathrm{g})\end{array}$ & $\begin{array}{c}\text { Berry diam } \\
(\mathrm{mm})\end{array}$ & $\begin{array}{c}\text { Percent soluble solids } \\
\text { of all harvests }\end{array}$ \\
\hline Hall & $\mathrm{SF}$ & Bronze & $10.6 \mathrm{~b}^{\mathrm{y}}$ & $26.2 \mathrm{~b}$ & $14.5 \mathrm{a}$ \\
Fry & $\mathrm{F}$ & Bronze & $11.9 \mathrm{a}$ & $27.2 \mathrm{a}$ & $14.6 \mathrm{a}$ \\
Lane & $\mathrm{SF}$ & Black & $10.1 \mathrm{bc}$ & $25.9 \mathrm{~b}$ & $16.3 \mathrm{a}$ \\
Tara & $\mathrm{SF}$ & Bronze & $10.3 \mathrm{bc}$ & $25.7 \mathrm{~b}$ & $12.7 \mathrm{~b}$ \\
Triumph & $\mathrm{SF}$ & Bronze & $9.4 \mathrm{c}$ & $25.1 \mathrm{~b}$ & $15.5 \mathrm{a}$ \\
Significance & & & $<0.001$ & $<0.001$ & $<0.001$ \\
\hline
\end{tabular}

${ }^{\mathrm{z}} \mathrm{SF}=$ self-fertile (perfect); $\mathrm{F}=$ female.

${ }^{\mathrm{y}}$ Mean separation within columns by Duncan's multiple range test, $P<0.05$, with $\mathrm{n}=4$.

Table 6. Colorimetric parameters of berry skins of 'Hall' and standard muscadine cultivars.

\begin{tabular}{lccc}
\hline Cultivar & Lightness $\left(\mathrm{L}^{*}\right)^{\mathrm{z}}$ & Chroma $\left(\mathrm{C}^{*}\right)^{\mathrm{y}}$ & Hue angle $\left(h^{\circ}\right)^{\mathrm{x}}$ \\
\hline Hall & $51.5 \mathrm{a}^{\mathrm{w}}$ & $15.1 \mathrm{a}$ & $100.9 \mathrm{bc}$ \\
Fry & $46.0 \mathrm{c}$ & $16.4 \mathrm{a}$ & $102.4 \mathrm{~b}$ \\
Tara & $48.4 \mathrm{~b}$ & $15.0 \mathrm{a}$ & $107.8 \mathrm{a}$ \\
Triumph & $38.6 \mathrm{~d}$ & $11.6 \mathrm{~b}$ & $98.6 \mathrm{c}$ \\
Significance & $<0.001$ & $<0.001$ & $<0.001$ \\
\hline
\end{tabular}

${ }^{2}$ The value of $L^{*}$ describes the degree of darkness or lightness with $\mathrm{L}=0$ being black and $\mathrm{L}=100$ white. ${ }^{\mathrm{y}} \mathrm{Richness}$ of color is represented by $\mathrm{C}^{*}$.

${ }^{\times} h^{\circ}$ represents the dominant color wavelength where $0^{\circ}=$ red-purple, $90^{\circ}=$ yellow, $180^{\circ}=$ bluish green, $270^{\circ}=$ blue

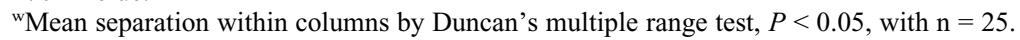

'Hall' is recommended as an early-season bronze muscadine for the fresh market. In general, 'Hall' is similar to its parent 'Tara' but has higher soluble solids content (Table $5)$, a lighter and more yellow berry color (Table 6), and, unlike 'Tara' (Conner, 2009), has not produced any off-flavors. The coldhardiness of 'Hall' has not been determined, but young vines have done well in Watkinsville, GA. 'Hall' is easily propagated by softwood cuttings rooted under mist during June and July.

\section{Availability}

'Hall' will be a patented cultivar (USPP applied for) and is owned by the University of Georgia Research Foundation. Propagation rights are controlled by the University of Georgia Research Foundation, Technology Commercialization Office, GSRC Boyd Building, Athens, GA 30602-7411 (<http:// www.ovpr.uga.edu/tco/>). A list of nurseries licensed to propagate 'Hall' muscadine can be obtained by contacting the author.

\section{Literature Cited}

Conner, P. 2009. Performance of muscadine grape cultivars in southern Georgia. J. Amer. Pomol. Soc. 63:101-107.

Conner, P. 2013. Instrumental textural analysis of muscadine germplasm. HortScience 48:1130 1134.

Lane, R. 1993. 'Tara' muscadine grape. HortScience 28:232.

McGuire, R. 1992. Reporting of objective color measurements. HortScience 27:1254-1255.

Poling, B., C. Mainland, W. Bland, B. Cline, and K. Sorenson. 2003. Muscadine grape production guide. N.C. State Ext. Serv. Bul. AG-94. 